\title{
PROFESORS HEINRIHS ŠNEIDERS - MUZEJA DRAUGS
}

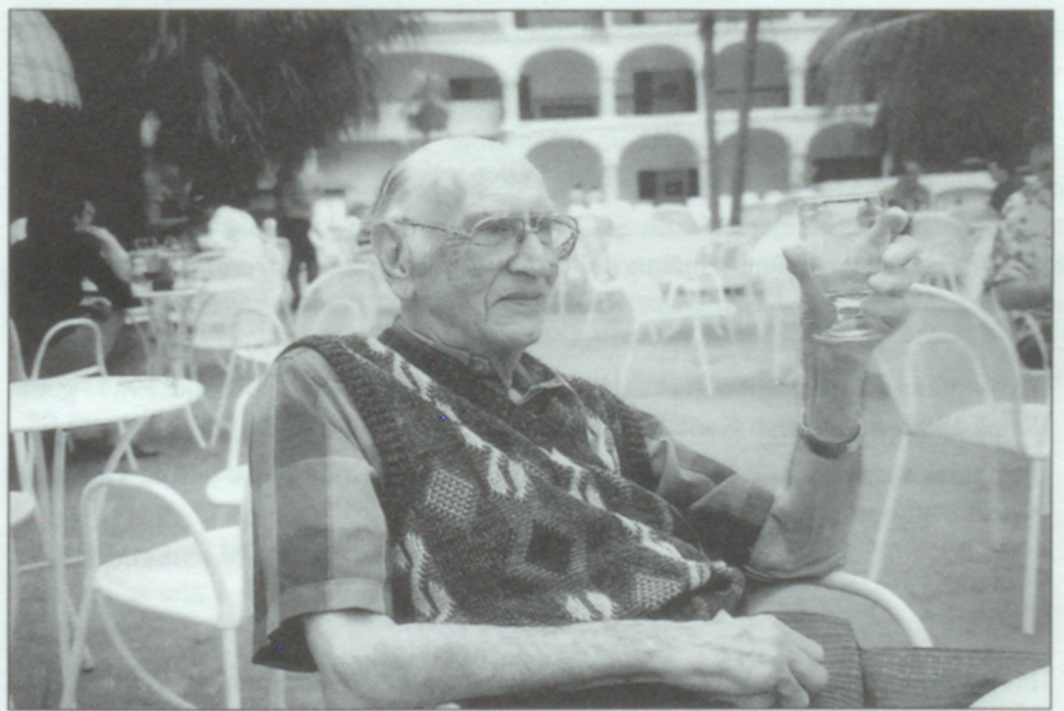

Profesors Heinrihs Šneiders Toronto 2000. gadā

Paula Stradina Medicīnas vēstures muzejam ir daudz draugu, to vidũ ir arī īpaši draugi. Mēs esam patiesi lepni un laimīgi, ja mūs atceras, ja domās un darbos ir kopā ar mums. Zinām arī to, ka grūtajā pārmainu laikā mūsu atbalstītāji gatavi nākt mums palīgā un atbalstīt gan morāliski, gan finansiāli. Sabiedrībai vajadzīgs muzejs un muzejam vajadzīgi draugi, jo muzejā glabājas ne tikai dokumentālas, bet arī memoriālas liecības.

Viens no muzeja labvēliem un draugiem ir profesors Heinrihs Šneiders, kas jau trīs gadu desmitus dzĩvo ãrpus Latvijas, taču joprojām atceras savu dzimto zemi Latviju, Rīgu un kādreizējos kolēgus. 
Paula Stradiña Medicīnas vēstures muzejā, kã arī muzejā "Ebreji Latvijā" glabājas visas profesora H. Šneidera sarakstîtās grāmatas, ar kurām šeit var iepazīties arī plašāka sabiedrība.

Profesors Heinrihs Šneiders finansiāli atbalstīja Paula Stradiṇa Medicīnas vēstures muzeja jauno ekspozīiju "Medicīna Rīgā 800 gados". Viṇš turpina savu mecenāta darbību, par ko viñam vissirsnīgākais paldies.

Profesors Heinrihs Šneiders dzimis 1910. gada 21. februârī Rīgã fabrikanta g̀imenē. Studējis Šveicē, Bāzeles universitātes Medicīnas fakultātē, ko beidzis 1934. gadā; Latvijas Universitātes diplomu ieguvis 1940. gadā.

No 1934. līdz 1940. gadam Dr. A. Šneiders strādājis Rīgā par ḳirurgu pie profesora Vladimira Minca (1872-1945) Bikur Holim slimnīcā. No 1941. līdz 1944. gadam viṇš ir k̦irurgs Čuvašijā (Marposadā, Vurnarā, Alatirā). Karam beidzoties, Dr. H. Śneiders atgriezies dzimtajā pilsētā. No 1945. līdz 1960. gadam viṇš bijis Rīgas 3. slimnīcas ḳirurg̀ijas noda|as vadītājs, bet no 1960. līdz 1973. gadam strādājis Rīgas Traumatologijas un ortopēdijas institūtā, kã arī Rīgas Medicīnas institūta Kara ķirurgijas un ortopēdijas katedrā.

1956. gadā H. Šneiders aizstāvējis medicīnas zinātṇu kandidāta disertāciju, bet 1968. gadā - medicīnas zinātṇu doktora disertāciju "Barības vada ekstirpācijas transdiafragmālās pieejas eksperimentāls un klīnisks pamatojums".

No 1973. līdz 1975. gadam H. Šneiders dzīvoja Izraēlā, no 1975. gada - Vācijā, Bādvildungenē, kur strādājis par ķirurgu līdz pat aiziešanai pensijā 1984. gadā. Kopš 1992. gada dzīvo Kanādā, Toronto.

Profesors Heinrihs Šneiders sarakstījis vairāk nekā 50 zinātnisku darbu; viṇš ir arī vairāku atmiṇu un dzejas grāmatu autors.

\section{Поздравляю Рига}

Рига 800 лет отмечает,

Я поздравляю от души,

Ее весь свет так хорошо ведь знает

И все большие прелести.

Рига боролась за свободу

И наконец все у нее

И к юбилейному ее ведь году

Живется ей так хорошо.

Мы ралы, счастливы, довольны,

Что дожили великий юбилей,

Который отмечает вольно

В кругу своих больших друзей.
Всегда я Ригу вспоминаю, Родился там уже давно, Как на бастионке я играю, На эспланаде еду на вело.

И школу в Риге я кончаю, Затем и университет, Затем я завотделом процветаю, Где я оставил в жизни след.

Мой 90-летний юбилей Музей Страдыня отмечает: И что я сделал для людей Вся Рига это знает. 
Желаю Риге от всего сердша

Все юбилеи отмечать.

Люблю ее, друзья, поверьте,

Ведь этот город - моя мать.

Profesora Heinriha Śneidera Paula Stradina Medicĩnas vēstures muzejam atsūtīts dzejolis, kas veltīts Rīgas 800 gadu jubilejai

\section{Professor Heinrich Schneider - a Friend of our Museum (Summary)}

By Maija Anže

The article gives a short survey of the life of the life of Paul Stradins Museum of History for Medicine friend and patron surgeon professor Heinrich Schneider living in Canada. H. Schneider was born in 1910 in Riga. He studied medicine at the University of Basel in Switzerland. From 1934-1940 he worked in Riga, at the Bikur Holim hospital. During the war he worked as a surgeon in the Chuvash republic. After the war he returned to Riga. He works at the 3rd Riga hospital, at the Riga Institute of Traumatology and Orthopaedics and at the Riga Medical Institute. He has defended 2 thesis; in 1956 - the candidate of medicine, and in 1968 - his doctor's thesis. Since 1973 he has lived abroad - in Israeli (1973-1975), in Germany (1975-1984) and in Canada since 1992. H. Schneider has written over 50 scientific works, several poetry and recollections.

Maija Anže, mag. hist.

Paula Stradiña Medicīnas vēstures muzejs

Antonijas iela 1, Rīga LV-1360

Latvija

E-mail: museum3@mailbox.riga.lv 
